\title{
Role of 2'-Hydroxycinnamaldehyde In The Induction of Apoptosis Via A Reactive Oxygen Species- Dependent JNK Pathway in Human Promyelocytic HL-60 Leukemia Cells
}

\section{Kyung-Sook Chung}

Kyung Hee University

\section{Chae-Bin Yoo}

Kyung Hee University

Jeong-Hun Lee

Kyung Hee University

Hwi-Ho Lee

Kyung Hee University

\section{Sang-Eun Park}

Kyung Hee University

Hee-Soo Han

Kyung Hee University

\section{Su-Yeon Lee}

Kyung Hee University

\section{Seung Yeon Jeong}

Kyung Hee University

\section{Byoung-Mok Kwon}

Korea Research Institute of Bioscience and Biotechnology

Jung-Hye Choi

Kyung Hee University

Kyung-Tae Lee ( $\nabla$ ktlee@khu.ac.kr)

Kyung Hee University https://orcid.org/0000-0002-3141-3727

\section{Research}

Keywords: 2'-hydroxycinnamaldehyde (2'-HCA), leukemia, reactive oxygen species (ROS), c-Jun N-terminal kinase (JNK), Bim

Posted Date: May 17th, 2021 
DOI: https://doi.org/10.21203/rs.3.rs-497892/v1

License: (c) (1) This work is licensed under a Creative Commons Attribution 4.0 International License. Read Full License 


\section{Abstract}

Background: Because the role and molecular mechanism of 2'-hydroxycinnamaldehyde (2'-HCA) in human leukemia need to be clarified, we provide detailed insights into the mechanism underlying the antiproliferative properties of 2'-HCA in acute myeloid leukemia (AML).

Methods: We performed MTT assay to examine the cytotoxic effect of 2'-HCA. 2'-HCA-induced apoptotic pathway was demonstrated by annexin V-FITC/ propidium iodide double staining, DAPI staining for DNA fragmentation detection, and western blot analysis. ROS generation, intracellular glutathione (GSH) level, and intracellular protein thiols (PSH) were detected to investigated the mechanism of 2'-HCA-related apoptosis. Xenograft animal model was used to evaluate anti-tumor activities of 2'-HCA.

Results: The present study demonstrated that 2'-HCA induced apoptosis in human promyelocytic leukemia HL-60 cells through the activation of mitochondrial pathways. 2'-HCA also induced the activation of JNK and the pharmacological inhibition of JNK effectively prevented 2'-HCA-induced apoptosis and AP-1-DNA binding. In addition, 2'-HCA resulted in the accumulation of ROS and depletion of intracellular GSH and PSH in HL-60 cells. Xenograft mice inoculated with HL-60 leukemia cells demonstrated that the intraperitoneal administration of 2'-HCA inhibited tumor growth by increasing of TUNEL staining, the expression levels of nitrotyrosine, pro-apoptotic proteins, and PCNA protein expression.

Conclusion: Our findings suggest that 2'-HCA induces apoptosis via the ROS-dependent JNK pathway and could be considered as a potential therapeutic agent for leukemia.

\section{Background}

Changes in cellular oxidative stress have emerged as a critical event in cancer. Intracellular reactive oxygen species (ROS), which are produced continuously by the mitochondria, have been suggested to regulate the processes involved in cancer cell cycle arrest, senescence, and apoptosis [1]. This can be achieved by reducing the levels of cellular antioxidants such as glutathione (GSH) and ROS including superoxide anion, nitric oxide, peroxynitrite, and hydrogen peroxide [2]. Elevated levels of ROS activate cellular signaling pathways such as mitogen-activated protein kinase (MAPK), nuclear factor kappa-B (NF-KB), Wnt, and Kelch-like ECH-associated protein 1 (Keap1)-nuclear factor (erythroid-derived 2)-like 2 (Nrf2), which can lead to apoptosis [3]. This may be attributed to an increase in mitochondrial oxidative stress that causes cytochrome $c$ release into the cytosol, leading to caspase activation. Several anticancer and chemopreventive agents generate ROS, which are associated with the apoptotic cell death of tumor cells [2].

Leukemia is a major hematological malignancy that causes mortality and morbidity in different age groups [4]. It is defined as the abnormal proliferation, clonality, and differentiation of immature hematopoietic cells in the bone marrow [5]. Leukemia can be classified into four common types: acute lymphocytic leukemia (ALL), chronic lymphocytic leukemia (CLL), acute myeloid leukemia (AML), and 
chronic myelogenous leukemia (CML). Among these types of leukemia, $\mathrm{AML}$ is characterized by the aggressive growth of hematopoietic precursor cells that interfere with the production of normal hematopoietic cells in the bone marrow [6]. Although refinement of supportive treatment has improved the outlook of patients with AML in the past 30 years, more than half of young adults and around $90 \%$ of older patients still die from AML [5]. The majority of AML cells express varying amounts of the transmembrane surface glycoprotein CD33 (observed in approximately $>80 \%$ of patients with $A M L$ ). Therefore, the FDA has granted accelerated approval to gemtuzumab ozogamicin (GO), which is a humanized monoclonal antibody that binds with the IgV domain of CD33 for older patients with relapsed CD33-positive AML [7]. In addition, CPX-351 (a dual drug liposomal encapsulation of cytarabine and daunorubicin), enasidenib (a selective oral inhibitor of the mIDH2 enzyme), and midostaurin (a multitargeted kinase inhibitor active in AML patients with an FLT3 mutation) were approved by the FDA in 2017. Although the past few years have been an active period for the clinical testing and FDA approval of various molecularly targeted treatments using novel agents for AML, there is limited information on side effects including hepatotoxicity, cardiotoxicity, hematotoxicity, and infection [8].

2'-Hydroxycinnamaldehyde (2'-HCA, Fig. 1), which is an active compound isolated from Cinnamomum cassia, is a cinnamaldehyde derivative [9]. 2'-HCA is known to have anti-tumor effects in various cancer cells, which include the prevention of cell proliferation and induction of apoptosis [10-12]. In addition, 2'HCA has been reported to exhibit various biological activities, including the suppression of $\beta$-catenin signaling and epithelial-mesenchymal transition (EMT) in cancer cells [13]. In addition, 2'-HCA has been found to suppress cancer cell proliferation and tumor growth via the activation of pyruvate kinase M2 [14] and signal transducer and activator of transcription 3 (STAT-3) by regulating ERK1/2 and ROS generation in prostate cancer cells [15]. Nevertheless, the role and molecular mechanism of 2'-HCA in human leukemia need to be clarified. In the present study, we provide detailed insights into the mechanism underlying the anti-proliferative properties of 2'-HCA in AML.

\section{Materials And Methods}

\section{Materials and cell culture}

2'-HCA was kindly provided by Dr. Byoung-Mok Kwon (KRIBB)[16]. Primary antibodies against Bax, Bcl-2, caspase-3, PARP-1, ASK-1, a-tubulin, and $\beta$-actin were purchased from Santa Cruz Biotechnology Inc (Santa cruz, CA, U.S.A.). Antibody against cytochrome $c$ and Annexin V-FITC apoptosis detection kit were purchased from BD Biosciences Pharmingen (San Jose, CA, USA). Antibodies against caspase-9, p-c-Jun, c-Jun, ASK-1, p-ERK1/2, ERK1/2, p-JNK, JNK, p-p38 MAPK, p38 MAPK, and COX-4 were purchased from Cell Signaling Technology (Danvers, MA, U.S.A). z-VAD-fmk, z-DEVD-fmk, and Ac-IETD-CHO were purchased from Calbiochem (Bad Soden, Germany). 3-(4,5-dimethylthiazol-2-yl)-2,5-diphenyl-tetrazolium bromide (MTT), 4',6-diamidino-2-phenylindole (DAPI), rhodamine 123, propidium iodide (PI), sodium dodecyl sulfate (SDS), dimethyl sulfoxide (DMSO), RNase A, 2',7'-dichlorofluorescein diacetate (DCFHDA), and other chemicals were purchased from Sigma Chemical Co (St.Louis, MO, U.S.A.). 
HL-60 human promyelocytic leukemia, Molt-4 human T lymphoblastic leukemia, U937 human histiocytic lymphoma, K562 human erythroleukemia, HepG2 human hepatoma, SNU-C5 human colorectal adenocarcinoma, A549 human lung adenocarcinoma, and KB human mouth epidermal carcinoma cells were obtained from the Korean Cell Line Bank (KCLB). Cells were cultured in RPMI 1640 or Dulbecco's modified Eagle's minimum essential medium (DMEM) with 10\% fetal bovine serum, penicillin (100 units $/ \mathrm{ml})$, and streptomycin sulfate $(100 \mu \mathrm{g} / \mathrm{ml})$. Cells were maintained at $37^{\circ} \mathrm{C}$ in a humidified atmosphere of $5 \% \mathrm{CO}_{2}$.

\section{MTT assay}

Cytotoxicity was measured using the MTT assay. The MTT assay was performed for cytotoxicity measurement using a modified method described [17]. Briefly, the cells $\left(5 \times 10^{4}\right)$ were seeded in each well containing $100 \mathrm{ml}$ of the medium in 96-well plate. After incubation for $24 \mathrm{~h}$, various concentrations of 2'HCA were added to the $96-$ well plate. After $48 \mathrm{~h}, 50 \mathrm{ml}$ of MTT ( $5 \mathrm{mg} / \mathrm{ml}$ stock solution in PBS) was added to each well for $4 \mathrm{~h}$. The medium was discarded and the formazan blue which formed in the cells was dissolved with $100 \mathrm{~mL}$ DMSO. The optical density was measured at $540 \mathrm{~nm}$.

\section{Annexin V-FITC/ propidium iodide (PI) double staining analysis}

After treatment with 2'-HCA, apoptotic cells were detected with Annexin V-FITC/PI kit (BD Bioscience Pharmingen, $\mathrm{CA}, \mathrm{USA}$ ), following the manufacturer's instruction and analyzed by the fluorescenceactivated cell sorting (FACS) cater-plus flow cytometry (Becton Dickinson Co, Heidelberg, Germany).

\section{Detection of DNA fragmentation}

DNA fragmentation was quantitated with DAPI assay as previously reported [18]. In brief, cells were lysed in a solution containing $5 \mathrm{mM}$ Tris- $\mathrm{HCl}(\mathrm{pH} 7.4), 1 \mathrm{mM}$ EDTA, and $0.5 \%(\mathrm{w} / \mathrm{v})$ Triton X-100 for $20 \mathrm{~min}$ on ice. After centrifugation at $27,000 \times g$ for $20 \mathrm{~min}$, the lysate and supernatant were sonicated for $40 \mathrm{~s}$, and the level of DNA was measured by a fluorometric method using DAPI. The amount of the fragmented DNA was calculated as the ratio of the amount of DNA in the supernatant to that in the lysate. The genomic DNA was prepared for gel electrophoresis as previously described [19]. Electrophoresis was performed in a $1.5 \%(\mathrm{w} / \mathrm{v})$ agarose gel in $40 \mathrm{mM}$ Tris-acetate buffer $(\mathrm{pH} 7.4)$ at $50 \mathrm{~V}$ for $1 \mathrm{~h}$. The fragmented DNA was visualized by staining with ethidium bromide after electrophoresis.

\section{Preparation of mitochondrial and cytosolic fraction and total protein}

$\mathrm{HL}-60$ cells $\left(2.5 \times 10^{7}\right)$ were collected by centrifugation at $200 \times g$ for $10 \mathrm{~min}$ at $4^{\circ} \mathrm{C}$. The cells were washed twice with ice-cold PBS, followed by centrifugation at $200 \times g$ for $5 \mathrm{~min}$. The cell pellet was then resuspended in cell lysis buffer (20 mM HEPES-KOH, pH 7.5, $10 \mathrm{mM} \mathrm{KCl}, 1.5 \mathrm{mM} \mathrm{MgCl}, 1 \mathrm{mM}$ EDTA, 1 $\mathrm{mM}$ EGTA, $1 \mathrm{mM}$ DTT, $100 \mathrm{mM}$ PMSF) for $30 \mathrm{~min}$ on ice. Cells were then homogenized with a glass dounce and a B-type pestle (80 strokes). Cell homogenates were spun at $15,000 \times g$ for $15 \mathrm{~min}$ at $4^{\circ} \mathrm{C}$ and the supernatant (cytosolic fraction) was removed while taking care to avoid the pellet. The resulting pellet 
was resuspended in mitochondrial buffer. For total cell protein extracts, cells were washed with ice-cold PBS and extracted in protein lysis buffer (Intron, Seoul, Korea) for 30 min on ice. Cells were then spun at $15,000 \times g$ for $30 \mathrm{~min}$ at $4^{\circ} \mathrm{C}$ and the supernatant (total protein) was used to detection for protein expression.

\section{Western blot analysis}

For western blot analysis, protein concentration was determined by Bradford assay. Protein samples were mixed with $5 \times$ SDS sample buffer, boiled for $4 \mathrm{~min}$, and then separated by SDS-PAGE gels. After electrophoresis, proteins were transferred to polyvinylidene difluoride membrane. The membranes were incubated with the primary antibody in Tris-buffered saline containing $0.1 \%$ Tween-20 (TBS-T) overnight at $4^{\circ} \mathrm{C}$. The primary antibody of the membrane was removed by washing in TBS-T and the membrane was incubated with horseradish peroxidase-conjugated secondary antibodies for $1 \mathrm{~h}$. Following washing in TBS-T, immune blots were visualized by ECL (GE Healthcare) and exposed to X-ray film (Amersham, NJ, USA).

\section{Determination of mitochondrial membrane potential $\left(D \Psi_{m}\right)$}

Changes in the $D \Psi_{m}$ were examined by monitoring the cells after double staining with $\mathrm{PI}$ and rhodamine 123. After treatment of $40 \mathrm{mM} 2$ '-HCA for $2 \mathrm{~h}$, the cells were incubated with medium containing $5 \mathrm{mg} / \mathrm{mL}$ rhodamine 123 for $1 \mathrm{~h}$ to determine the mitochondrial membrane potential. The cells were resuspended in $1 \mathrm{~mL}$ of minimal essential medium containing $5 \mathrm{mg}$ of PI to assess cell viability. The intensity of fluorescence from $\mathrm{PI}$ and rhodamine 123 was measured by flow cytometry. Fluorescence was measured after the cells staining for $30 \mathrm{~min}$ at $37^{\circ} \mathrm{C}$.

\section{Detection of ROS generation}

To measure 2'-HCA-induced intracellular ROS level, we used DCFH-DA, which is the most widely used fluorescent probe for the detection of intracellular oxidative stress [20]. The 2'-HCA-treated cells were incubated with $20 \mathrm{mM} \mathrm{DCFH-DA}$ for $30 \mathrm{~min}$ at $37^{\circ} \mathrm{C}$. The intracellular ROS level was measured by flow cytometry.

\section{Determination of the GSH level}

Cells were washed twice with PBS and treated with $5 \%$ trichloroacetic acid (TCA) to extract cellular GSH. The mixture was centrifuged at $13,000 \times g$ for $1 \mathrm{~min}$ to remove the denatured proteins. GSH was determined by the enzymatic method as previously described [21]. To determine the glutathione disulfide (GSSG), the same DTNB recycling assay was performed after using 2-vinylpyridine to remove the reduced GSH [22]. Briefly, $2 \mu \mathrm{L}$ of 2-vinylpyridine and $6 \mu \mathrm{L}$ of triethanolamine were simultaneously mixed with 100 $\mu \mathrm{L}$ of sample, followed by incubation in the dark at room temperature for $1 \mathrm{~h}$ before initiation of the recycling assay. The kinetics of the reaction was monitored for $10 \mathrm{~min}$. The increment in absorbance at $412 \mathrm{~nm}$ was converted to GSH concentration using a standard curve with known amounts of GSH. 


\section{Measurement of intracellular protein thiols (PSH)}

To measure the intracellular PSH, we performed the assay of intracellular PSH as previously report [22]. Briefly, cells were treated with 5\% TCA and then vortexed and kept on ice for 30 min to prepare complete protein precipitation. After centrifugation, the protein precipitate dissolved in $0.1 \mathrm{M}$ Tris- $\mathrm{HCl}$ buffer $(\mathrm{pH}$ 7.5), containing $5 \mathrm{mM}$ EDTA and $0.5 \%$ sodium dodecyl sulfate (SDS). One aliquot of this protein precipitate was reacted with a solution containing $0.1 \mathrm{M}$ sodium phosphate buffer ( $\mathrm{pH} 7.5), 5 \mu \mathrm{M}$ EDTA, $0.6 \mathrm{mM}$ DTNB, $0.2 \mathrm{mM} \mathrm{NADPH}, 1 \mathrm{unit} / \mathrm{ml}$ glutathione reductase, and another aliquot of the protein solution was treated with $5 \mathrm{mM} N$-ethylmaleimide (NEM) before the reaction to obtain the background value for subtraction. The concentration of intracellular protein thiol was expressed as nmol of $\mathrm{SH}$ equivalents/mg protein using GSH as a standard.

\section{Caspase -3 activity assay}

The caspase-3 activity was measured using a fluorogenic caspase-3 substrate (Ac-DEVD-AFC). Cells were washed once with PBS, resuspended in $400 \mu$ of lysis buffer $(20 \mathrm{mM} \mathrm{HEPES}, \mathrm{pH} 7.4,100 \mathrm{mM} \mathrm{NaCl}, 0.5 \%$ $\mathrm{NP}-40,10 \mathrm{mM}$ DTT) and incubated on ice for $30 \mathrm{~min}$. After centrifugation (12,000 $\times \mathrm{g}$ for $5 \mathrm{~min})$, supernatants were collected and immediately measured for protein concentration and caspase activity, or stored at $-70^{\circ} \mathrm{C}$ until assayed. For the activity assay, $100 \mu \mathrm{L}$ of cell lysates were placed in a 96 -well plate and a caspase substrate was added to each well. Plates were incubated at $37^{\circ} \mathrm{C}$ for $1 \mathrm{~h}$ and caspase activity was determined from the fluorescence read at $505 \mathrm{~nm}$ induced by excitation at $400 \mathrm{~nm}$.

\section{Transfection for RNA interference}

Control small interfering RNA (siRNA) and JNK targeting siRNA (5'-AAAAAGAATGTCCTACCTTCT-3') specific for humans and mice were obtained from Santa Cruz Biotechnology (Santa cruz, CA, U.S.A.). HL60 cells $\left(2 \times 10^{6}\right)$ were transfected with siRNA $(200 \mathrm{nM})$ by RNAiFect transfection reagent (QIAGEN, Hilden, Germany) according to recommendations of the manufacturer. After transfection for $48 \mathrm{~h}$, cells were treated with 2'-HCA for $8 \mathrm{~h}$ and subjected to analysis.

\section{C-Jun N-terminal kinase (JNK) kinase assay}

To determine JNK kinase activity, JNK assay kit (Cell Signaling Technology, Danvers, MA, U.S.A.) was used according to the manufacture's instruction

\section{Electrophoretic mobility shift assay (EMSA)}

HL-60 cells $\left(5 \times 10^{6}\right.$ cells) were collected by centrifugation at $200 \times \mathrm{g}$ for $10 \mathrm{~min}$ at $4{ }^{\circ} \mathrm{C}$. The cells were washed twice with ice-cold PBS, pH 7.2, followed by centrifugation at $200 \times \mathrm{g}$ for 5 min. Nuclear extracts and EMSA assay were performed as described previously [23].

\section{Animals}


The male BALB/c nude mice (6-week-old, 20-23 g) were obtained from Nara Biotec Co. (Pyeongtaek, Republic of Korea). Mice were inhabited 6/cage/group and were had standard laboratory chow in an animal room with $12 \mathrm{~h}$ dark/light cycles at a constant temperature of $20 \pm 5^{\circ} \mathrm{C}$. All animal experiments were performed under university guidelines and were approved by the ethical committee for Animal Care and Use of Kyung Hee University according to the animal protocol (KHUASP(SE)-19-027).

\section{Xenograft animal model}

The male BALB/c nude mice were subjected to $150 \mathrm{mg} / \mathrm{kg}$ cyclophosphamide (CYP) by intraperitoneal (i.p.) injection three times per two days (Fig. 2). After CYP injection, HL-60 cells $\left(1 \times 10^{6}\right.$ per site) were inoculated subcutaneously into the right side of the flank of male BALB/c nude mice. Tumor size was checked with a caliper [24] once per 3 days in a week and calculated as $V=\pi / 6 \times($ length $) \times(\text { width })^{2}$. When tumor volume reached around $300 \mathrm{~mm}^{3}$, mice were divided into 5 groups and treated with vehicle (DMSO: Cremophor: D.W. = 1:3:16, i.p.), paclitaxel (PTX; positive control, 5 mg/kg, i.p.) and 2'-HCA (5, 10, or $20 \mathrm{mg} / \mathrm{kg}$, i.p.). During the treatment, tumor volume and body weight were measured once per 3 days. On day 21, mice were killed and tumors were obtained.

\section{Immunohistochemistry (IHC)}

Tumor tissues were washed and cleaned by $1 \times$ PBS to fixation with $4 \%$ paraformaldehyde. After tumor fixation, the tissues were embedded in paraffin. Tissue section and IHC were performed by Korea Experimental Pathology Inc. (Gyeonggi-do, Korea) and the immune-stained slides were viewed under a light microscope (400x).

\section{Statistical analysis}

All data presented as means \pm SD were analyzed by using GraphPad Prism 8.0 Software (San Diego, CA, USA). Student's $t$-test analysis was applied for statistical analysis to compare all the different groups in the current study. The difference was considered to have statistical significance if $P<0.05$.

\section{Results}

\section{2'-HCA induces apoptosis in HL-60 cells}

Initially, we performed MTT assay to examine the cytotoxic effect of 2'-HCA on various cancer cells (Table 1). Among the tested cancer cell lines, $\mathrm{HL}-60$ and Molt-4 were more susceptible to 2'-HCA. Subsequently, we examined whether the cytotoxicity of 2'-HCA is attributed to apoptotic cell death. As shown in Fig. 3A, Annexin V-positive cells (early apoptotic cells) were increased in a time-dependent manner after the treatment of the HL-60, Molt-4, U937, and K562 leukemia cells with 2'-HCA. In agreement with the results of MTT assay, 2'-HCA-induced apoptosis was most pronounced in HL-60 cells. Therefore, we selected HL60 cells to further investigate the apoptotic mechanism. As shown in Fig. 3B and 3C, 2'-HCA increased the quantification and laddering pattern of internucleosomal DNA fragmentation in HL-60 cells. These results 
indicated that 2'-HCA-induced leukemia cell death was caused by apoptosis and that HL-60 cells were highly reactive with 2 '-HCA.

\section{2'-HCA-induced apoptosis is involved in mitochondrial dysfunction and caspase activations in HL-60 cells}

The process of cell death may involve mitochondrial dysfunction including the release of cytochrome $c$ from the mitochondria by inducing the oligomerization of Bcl-2 family proteins, which subsequently causes apoptosis via caspase activation [25]. Treatment with $10 \mu \mathrm{M}$ 2'-HCA time-dependently increased the translocation of Bim and Bax from the cytosol to mitochondria and cytochrome $c$ release from the mitochondria into the cytosol, and cellular Bcl-2 protein levels were reduced (Fig. 4A). As cytochrome $c$ release is caused by $\Delta \psi_{m}$ disruption, we next evaluated the effect of 2'-HCA on $\Delta \Psi_{m}$ by flow cytometry after double staining with Rh123 and PI (Fig. 4B). The results showed that control cells appeared mostly on the Rh123 high-fluorescence (+) PI (-) (lower right quadrant) field, whereas 2'-HCA-treated HL-60 cells showed an increasing cell population on the Rh123 low-fluorescence (-) PI (-) (lower left quadrant) field. Furthermore, we examined the time-dependent proteolytic cleavage of procaspase-9, procaspase-3, and PARP-1 in HL-60 cells; however, the cleavage of procaspase-8 was not detected (Fig. 4C). To determine whether caspase activation is required for 2'-HCA-induced apoptosis, we pretreated HL-60 cells with caspase inhibitors. As shown in Fig. 4D, z-VAD-FMK (a broad caspase inhibitor) and z-DEVD-FMK (a caspase-3 inhibitor) inhibited 2'-HCA-induced DNA fragmentation, whereas Ac-IETD-CHO (a caspase-8 inhibitor) did not affect 2'-HCA-induced apoptosis. These observations indicated that the caspasedependent mitochondrial intrinsic pathway could be involved in 2'-HCA-induced apoptosis.

\section{2'-HCA-induced apoptosis is regulated by JNK activation in HL-60 cells}

Among the various signaling pathways that respond to stress, the mitogen-activated protein kinase (MAPK) signaling pathway is crucial for apoptosis [26]. To investigate signal transduction events that could contribute to apoptosis, we determined the role of the MAPK pathway in 2'-HCA-treated HL-60 cells. We found that the exposure of HL-60 cells to 2'-HCA resulted in a time-dependent increase in the phosphorylation of apoptosis signal-regulating kinase-1 (ASK-1), JNK, and ERK1/2 but not p38 MAPK (Fig. 5A). ASK-1, JNK, and ERK1/2 activation was evident as early as $15 \mathrm{~min}$ after treatment with $10 \mu \mathrm{M}$ 2'-HCA and persisted for the duration of the experiment in HL-60 cells. Commercially available p-JNK inhibitor (SP600125), ERK1/2 inhibitor (U0126), and p38 MAPK inhibitor (SB203580) were used to further determine whether 2'-HCA exerts its sensitizing effects by inhibiting p-JNK, p-ERK1/2, and p-38 MAPK. Interestingly, among the MAPK inhibitors, SP600125 pretreatment significantly inhibited 2'-HCA-induced DNA fragmentation, whereas there was no protective effect by either U0126 (ERK1/2 inhibitor) or SB203580 (p38 MAPK inhibitor) pretreatment up to $8 \mathrm{~h}$ (Fig. 5B). To rule out the possibility of the nonspecific effect of 2'-HCA on JNK, we analyzed the effect of JNK silencing. As shown in Fig. 5C and 5D, the knockdown of JNK by siRNA markedly blocked 2'-HCA-induced PARP-1 cleavage and DNA fragmentation in HL-60 cells, which were similar to the effects observed following treatment with the chemical inhibitor SP600125. JNK modulates the apoptotic pathway including the activation of specific transcription factors [27]. We evaluated JNK activity and AP-1 DNA-binding activity with JNK kinase 
assay and EMSA, respectively, in 2'-HCA-treated HL-60 cells. As shown in Fig. 5E and 5F, JNK and AP-1 DNA-binding activities were significantly increased by treatment with $10 \mu \mathrm{M}$ 2'-HCA within $2 \mathrm{~h}$, which was earlier than the onset of apoptosis as detected by caspase-3 activation and apoptotic DNA fragmentation. These observations indicated that the JNK pathway could play a crucial role in 2-HCAinduced apoptosis via the regulation of transcription factors.

\section{Oxidative stress is required for 2'-HCA-induced apoptosis in HL-60 cells}

ROS have been demonstrated to be an early signal that mediates apoptosis [28]. Indeed, it has been reported that 2'-HCA could induce the apoptosis of cancer cells mainly through ROS generation $[11,15]$. To confirm whether ROS are involved in 2'-HCA-mediated apoptosis in leukemia cells, we measured the levels of cellular ROS using DCFH-DA with a fluorescence microscope. As shown in Fig. 6A, marked ROS generation was observed in 5min after treatment with $10 \mu \mathrm{M}$ 2'-HCA, and the 2'-HCA-induced ROS generation was significantly reduced with antioxidant $\mathrm{N}$-acetylcysteine (NAC) pretreatment (Fig. 6B). As increasing evidence has suggested that the intracellular thiol redox status is one of the key mediators of apoptosis in many cell systems [29], we examined whether 2'-HCA-induced apoptosis involves the depletion of intracellular thiols. 2'-HCA rapidly reduced the levels of intracellular GSH and PSH in a timeand concentration-dependent manners and a statistically significant difference was detected as early as 15 min after treatment with various concentrations $(2.5,5$, or $10 \mu \mathrm{M}$ ) of 2'-HCA (Fig. 6C and 6D). To examine whether the generation of ROS is a crucial step in 2'-HCA-induced apoptosis, we investigated the effect of NAC on 2'-HCA-induced apoptosis. As shown in Fig. 6E and 6F, pretreatment with NAC decreased the 2'-HCA-induced sub-G ${ }_{1}$ cell population and abrogated the translocation of Bim and Bax from the cytosol to mitochondria, reduction of Bcl-2 protein expression, and release of cytochrome $c$ into the cytosol. In addition, pretreatment with NAC significantly attenuated 2'-HCA-induced caspase-3 activity in HL-60 cells (Fig. 6G). These results demonstrated that oxidative stress could play an important role in 2'HCA-induced apoptosis in HL-60 cells.

\section{Reduced oxidative stress attenuates the 2'-HCA-induced JNK pathway and mitochondrial translocation of Bim in HL-60 cells}

ROS can promote the activation of JNK, which modulates the activity of the proapoptotic BH3 subgroup of Bcl-2 family proteins such as Bim [1]. As 2'-HCA activated the JNK pathway and AP-1 transcription factor activity, we investigated whether the JNK pathway is associated with oxidative stress in 2'-HCAtreated HL-60 cells. As shown in Fig. 7A, pretreatment with NAC effectively attenuated 2'-HCA-induced ASK-1 protein expression and JNK phosphorylation but did not affect the phosphorylation of ERK1/2 and p38 MAPK. In addition, pretreatment with NAC completely inhibited 2'-HCA-induced AP-1 DNA-binding activity, indicating oxidative stress-regulated JNK/AP-1 signaling in HL-60 cells (Fig. 7B). Furthermore, our results revealed that the mitochondrial translocation of Bim was blocked by treatment with NAC and SP600125, indicating the important role of Bim in the 2'-HCA-activated ROS/JNK pathway (Fig. 7C). These results demonstrated that 2'-HCA-induced apoptosis could mediate mitochondrial dysfunction through mitochondrial Bim translocation regulated by the ROS/JNK pathway in HL-60 cells. 


\section{2'-HCA suppresses tumor growth in a HL-60 xenograft mouse model}

To evaluate the anti-tumor effect of 2'-HCA, we made a subcutaneous xenograft model of HL-60 cells in immunodeficient mice [30]. As shown in Fig. 8A, the average tumor volume was similar in each group at the start of the experiment. After intraperitoneal administration of 2'-HCA, tumor growth was slower than that of the vehicle-treated control group, and the tumor volume was markedly decreased from day 10 . In addition, on the last day of the experiment, the tumor volume was significantly smaller in the 2'-HCA administration group $\left(20 \mathrm{mg} / \mathrm{kg}\right.$, i.p.) than in the control group $\left(2525.77 \pm 1316.10 \mathrm{~mm}^{3} \mathrm{vs} .780 .47 \pm\right.$ $\left.665.28 \mathrm{~mm}^{3}, P<0.001\right)$. Consistently, IHC results showed the marked reduction of the proliferating cell nuclear antigen (PCNA) marker of proliferating cells in the tumor tissues of 2'-HCA-treated mice (Fig. 8C). Similar to in vitro results, 2'-HCA treatment increased the expression levels of nitrotyrosine, a marker of ROS, and enhanced apoptosis induction, as demonstrated by TUNEL staining of tumor tissues. Furthermore, western blotting revealed that treatment with 2'-HCA increased the levels of ASK-1, p-JNK, and the pro-apoptotic mediator Bim, resulting in the cleavage of PARP-1 (Fig. 8D). During the experimental period, 2'-HCA administration did not affect the body weight, and 2'-HCA showed no toxicity in the HL-60 xenograft mouse model (Fig. S1). Taken together, our findings indicated that 2'-HCA could inhibit tumor growth in vivo via ROS generation and JNK activation, which was consistent with the in vitro finding showing apoptosis induction via the ROS-dependent JNK pathway.

\section{Discussion}

ROS play a vital role in various cellular processes under physiological and pathological conditions. Excessive cellular levels of ROS can trigger oxidative stress, which is defined as a severe redox imbalance between the generation of ROS and antioxidant defenses, causing oxidative damage [31]. A moderate increase in ROS can promote cell differentiation and proliferation; however, excessive ROS accumulation causes oxidative stress and damage to cells [32]. Therefore, the anti-tumorigenic signaling of ROS may be targeted in cancer therapy by increasing the production of ROS to toxic levels and exhausting the antioxidant system [33]. Indeed, several studies have reported promising compounds that could elicit ROS generation, leading to apoptosis [34,35]. In our previous studies, we found that costunolide induced apoptosis in human ovarian cancer and leukemia cells via ROS generation and JNK activation [22, 36, 37], and cinnamaldehyde induced apoptosis via ROS-mediated mitochondrial permeability transition in HL-60 cells [38]. 2'-HCA, which is a derivative of cinnamaldehyde, also induced ROS-mediated apoptosis with STAT-3 activation, which was abrogated by GSH or NAC treatment in DU145 cells [15]. Although 2'HCA can inhibit the growth of human erythroleukemia or skin cancer cells by directly targeting Pim-1 kinase [39], limited studies have been conducted on the ROS-related molecular mechanism of 2'-HCA in human leukemia cells. Therefore, in the present study, we investigated the ROS-mediated anticancer mechanism of 2'-HCA in HL-60 cells. Interestingly, compared with our previous findings, the results here indicated that 2'-HCA $\left(\mathrm{IC}_{50}=4.17 \mu \mathrm{M}\right)$ was more cytotoxic than cinnamaldehyde $\left(\mathrm{IC}_{50}=30.7 \mu \mathrm{M}\right)$ in $\mathrm{HL}$ 60 cells. It is known that the aldehyde group of the side chain and free hydroxy-substituted groups play a critical role in the anti-tumor activity of cinnamaldehydes [40]. Therefore, we believe that the increased 
cytotoxicity of 2'-HCA may be attributed to a difference in the structure of the H group at the 2'-site of cinnamaldehyde, which is displaced by the hydroxyl group. 2'-HCA induced intracellular ROS generation in HL-60 cells, as detected by the ROS-sensitive fluorescent dye DCFH-DA, which is used as a probe for the specific detection of intracellular hydrogen peroxide rather than superoxide radicals. Similar to our in vitro results, 2'-HCA increased the expression of nitrotyrosine, which can be targeted to elevate cellular ROS levels in tumor tissues. Moreover, we found that pretreatment with NAC abrogated mitochondriadependent apoptosis including the translocation of Bim and Bax from the cytosol to mitochondria and the release of cytochrome $c$ into the cytosol in 2'-HCA-treated HL-60 cells. These results suggest the involvement of oxidative stress in 2'-HCA-induced intrinsic mitochondrial apoptosis in HL-60 cells.

ROS have been implicated in the activation of various cellular signaling pathways including MAPK, which can activate cell survival and/or cell death processes such as apoptosis [41]. ASK-1, a member of the MAPK kinase kinase (MAPKKK or MAP3K) family, is part of the MAPK cascade and binds to reduced thioredoxin in non-stressed cells. Under oxidative stress, thioredoxin is oxidized and dissociates from ASK-1, leading to the activation of MAPK pathways, which can promote apoptosis [42, 43]. Consistently, 2'-HCA induced a marked increase in ASK-1 protein expression and the phosphorylation of ERK1/2 and JNK in this study. However, the SP600125 JNK inhibitor but not the U0126 ERK1/2 inhibitor significantly reduced 2'-HCA-induced DNA fragmentation in HL-60 cells. Furthermore, pretreatment with NAC attenuated the 2'-HCA-activated DNA-binding activity of AP-1, which is downstream of JNK. We found that ROS could function as an up-regulator of the JNK pathway in 2'-HCA-treated HL-60 cells. The nuclear transcription factor AP-1, which is a heterodimer composed of c-Fos and c-Jun proteins, is often portrayed as a nuclear decision-maker that determines cell survival or death in response to cellular stimuli. Some studies have focused on its role in extrinsic apoptosis via JNK, c-Jun/AP-1, and Fas ligand (FasL) in lymphocytes $[44,45]$. AP-1 transcriptional activity is required for the mRNA expression of Bim, which is a crucial apoptosis regulator that induces Bax activation by inhibiting anti-apoptotic proteins such as Bcl-2 and Mcl-1; this results in increased mitochondrial permeability and apoptosis [46]. In the present study, pretreatment with a JNK inhibitor suppressed not only the DNA-binding activity of AP-1 but also the mitochondrial translocation of Bim in 2'-HCA-treated HL-60 cells. Our in vitro results were further confirmed in a xenograft animal model, which showed an increased expression level of Bim in 2'-HCAtreated tumor tissues. These results indicated that 2'-HCA-induced AP-1 activation upregulated the mRNA expression of Bim, leading to the loss of mitochondrial membrane integrity and resulting in apoptosis. The correlation between in vitro and in vivo observations supports this mechanistic explanation. In addition to the AP-1-responsive gene expression of the JNK pathway, it has been reported that ROSmediated JNK activation can regulate the phosphorylation and downregulation of anti-apoptotic Bcl-2 proteins [47]. JNK alters the composition of the Bax/Bcl-2 complex by increasing the expression of Bax, leading to the formation of Bax homodimers and resulting in the opening of the mitochondrial permeability transition pore [48]. Consistent with these findings, our results indicated that 2'-HCA induced a time-dependent increase in conformationally changed Bax (Bax/6A7) based on immunoprecipitation with an antibody directed against the $\mathrm{NH}_{2}$-terminal region of Bax (Fig. S2), suggesting that JNK activation may play a crucial role in the 2'-HCA-induced intrinsic apoptosis pathway in HL-60 cells. 


\section{Conclusion}

Taken together, the current study demonstrated that 2'-HCA could induce apoptosis in human promyelocytic leukemia HL-60 cells via the ROS-dependent JNK pathway involving AP-1-DNA binding, which in turn may increase Bim protein expression, leading to mitochondrial translocation and the subsequent disruption of $\Delta \psi_{m}$. Our findings suggest that 2'-HCA could be a useful pharmacologic tool for improving our understanding of basic cellular functions and that 2'-HCA may be considered as a potential therapeutic agent for human leukemia.

\section{Abbreviations}

2'-HCA: 2'-hydroxycinnamaldehyde; $\Delta \Psi_{m}$ : mitochondria membrane potential; JNK: c-Jun N-terminal kinase; ERK: extracellular signal regulated kinases ; AP-1: activator protein-1; GSH: glutathione; PSH: protein thiols; GSSG: glutathione disulfide; TCA: trichloroacetic acid; SDS: sodium dodecyl sulfate; NEM: $N$-ethylmaleimide; TUNEL: terminal deoxynucleotidyl transferase dUTP nick end labeling; ROS: reactive oxygen species; AML: acute myeloid leukemia; DCFH-DA: 2',7'-dichlorofluorescein diacetate; FACS: fluorescence-activated cell sorting; DAPI: 4',6-diamidino-2-phenylindole; TBS: tris-buffered saline; PI: propidium lodide; CYP: cyclophosphamide

\section{Declarations}

\section{Ethics approval and consent to participate}

This study was approved by the ethics committee of Kyung Hee University (Seoul, Republic of Korea). Experimental procedures involving the use of mice and care were conducted in accordance with institutional guidelines and compliance.

\section{Consent for publication}

Not applicable.

\section{Availability of data and materials}

All data generated or analyzed during this study are included in this published article and its supplementary information files.

\section{Competing interests}

The authors declare no competing interests.

\section{Funding}

This research was supported by Basic Science Research Program through the National Research Foundation of Korea (NRF) funded by the Ministry of Science and ICT (NRF-2017R1A5A2014768) and 
supported by the National Research Foundation of Korea (NRF) grant funded by the Korea government (MSIT) (2019R1F1A1058332).

\section{Author's contributions}

K.-T.L. and K.-S.C. conceived and designed the study. C.-B.Y., J.-H.L., H.-H.L., S.-E.P., H.-S.H. performed the experiments. B.-M.K. and J.-H.C. contributed materials and analyzed the data, respectively. K.-S.C. and K.T.L. wrote the paper. All authors read and approved the final manuscript. All authors read and approved final version of the manuscript.

\section{Author details}

${ }^{1}$ Department of Pharmaceutical Biochemistry, College of Pharmacy, Kyung Hee University, 26 Kyungheedae-ro, Seoul 02447, Republic of Korea. ${ }^{2}$ Department of Life and Nanopharmaceutical Science, College of Pharmacy, Kyung Hee University, 26 Kyungheedae-ro, Seoul 02447, Republic of Korea. ${ }^{3}$ Department of Biomedical and Pharmaceutical Sciences, College of Pharmarcy, Kyung Hee University, Seoul 02447, Republic of Korea. ${ }^{4}$ Department of Fundamental Pharmaceutical Science, Graduate School, Kyung Hee University, Seoul 02447, Korea. ${ }^{5}$ Laboratory of Chemical Biology and Genomics, Korea Research Institute of Bioscience and Biotechnology, Daejeon, Republic of Korea. ${ }^{6}$ Oriental Pharmaceutical Science, College of Pharmacy, Kyung Hee University, 26 Kyungheedae-ro, Seoul 02447, Republic of Korea

\section{References}

1. Redza-Dutordoir M, Averill-Bates DA: Activation of apoptosis signalling pathways by reactive oxygen species. Biochim Biophys Acta 2016, 1863(12):2977-2992. https://doi.org/10.1016/j.bbamcr.2016.09.012.

2. Moldogazieva NT, Mokhosoev IM, Feldman NB, Lutsenko SV: ROS and RNS signalling: adaptive redox switches through oxidative/nitrosative protein modifications. Free Radic Res 2018, 52(5):507543. https://doi.org/10.1080/10715762.2018.1457217.

3. Espinosa-Diez C, Miguel V, Mennerich D, Kietzmann T, Sanchez-Perez P, Cadenas S, Lamas S: Antioxidant responses and cellular adjustments to oxidative stress. Redox Biol 2015, 6:183-197. https://doi.org/10.1016/j.redox.2015.07.008.

4. Salah HT, Muhsen IN, Salama ME, Owaidah T, Hashmi SK: Machine learning applications in the diagnosis of leukemia: Current trends and future directions. Int J Lab Hematol 2019, 41(6):717-725. https://doi.org/10.1111/ijlh.13089.

5. Huang Q, Wang L, Ran Q, Wang J, Wang C, He H, Li L, Qi H: Notopterol-induced apoptosis and differentiation in human acute myeloid leukemia HL-60 cells. Drug Des Devel Ther 2019, 13:19271940. https://doi.org/10.2147/DDDT.S189969. 
6. Kim HS, Lim GY, Hwang J, Ryoo ZY, Huh TL, Lee S: Induction of apoptosis by obovatol as a novel therapeutic strategy for acute myeloid leukemia. Int J Mol Med 2014, 34(6):1675-1680. https://doi.org/10.3892/ijmm.2014.1957.

7. Lai C, Doucette K, Norsworthy K: Recent drug approvals for acute myeloid leukemia. J Hematol Oncol 2019, 12(1):100. https://doi.org/10.1186/s13045-019-0774-x.

8. Wu Q, Lv T, Chen Y, Wen L, Zhang J, Jiang X, Liu F: Apoptosis of HL-60 human leukemia cells induced by Asiatic acid through modulation of B-cell lymphoma 2 family proteins and the mitogen-activated protein kinase signaling pathway. Mol Med Rep 2015, 12(1):1429-1434.

https://doi.org/10.3892/mmr.2015.3534.

9. Ahn SG, Jin YH, Yoon JH, Kim SA: The anticancer mechanism of 2'-hydroxycinnamaldehyde in human head and neck cancer cells. Int J Oncol 2015, 47(5):1793-1800.

https://doi.org/10.3892/ijo.2015.3152.

10. Lee CW, Hong DH, Han SB, Park SH, Kim HK, Kwon BM, Kim HM: Inhibition of human tumor growth by 2'-hydroxy- and 2'-benzoyloxycinnamaldehydes. Planta Med 1999, 65(3):263-266. https://doi.org/10.1055/s-2006-960772.

11. Han DC, Lee MY, Shin KD, Jeon SB, Kim JM, Son KH, Kim HC, Kim HM, Kwon BM: 2'benzoyloxycinnamaldehyde induces apoptosis in human carcinoma via reactive oxygen species. $J$ Biol Chem 2004, 279(8):6911-6920. https:// doi.org/10.1074/jbc.M309708200.

12. Moon EY, Lee MR, Wang AG, Lee JH, Kim HC, Kim HM, Kim JM, Kwon BM, Yu DY: Delayed occurrence of H-ras12V-induced hepatocellular carcinoma with long-term treatment with cinnamaldehydes. Eur J Pharmacol 2006, 530(3):270-275. https://doi.org/10.1016/j.ejphar.2005.11.053.

13. Ismail IA, Kang HS, Lee HJ, Chang H, Yun J, Lee CW, Kim NH, Kim HS, Yook JI, Hong SH et al: 2Hydroxycinnamaldehyde inhibits the epithelial-mesenchymal transition in breast cancer cells. Breast Cancer Res Treat 2013, 137(3):697-708. https://doi.org/10.1007/s10549-012-2388-7.

14. Yoon YJ, Kim YH, Jin Y, Chi SW, Moon JH, Han DC, Kwon BM: 2'-hydroxycinnamaldehyde inhibits cancer cell proliferation and tumor growth by targeting the pyruvate kinase M2. Cancer Lett 2018, 434:42-55. https://doi.org/10.1016/j.canlet.2018.07.015.

15. Yoon YJ, Kim YH, Lee YJ, Choi J, Kim CH, Han DC, Kwon BM: 2'-Hydroxycinnamaldehyde inhibits proliferation and induces apoptosis via signal transducer and activator of transcription 3 inactivation and reactive oxygen species generation. Cancer Sci 2019, 110(1):366-378. https://doi.org/10.1111/cas.13852.

16. Kwon BM, Cho YK, Lee SH, Nam JY, Bok SH, Chun SK, Kim JA, Lee IR: 2'-Hydroxycinnamaldehyde from stem bark of Cinnamomum cassia. Planta Med 1996, 62(2):183-184. https://doi.org/10.1055/s-2006-957851.

17. Plumb JA, Milroy R, Kaye SB: Effects of the pH dependence of 3-(4,5-dimethylthiazol-2-yl)-2,5diphenyl-tetrazolium bromide-formazan absorption on chemosensitivity determined by a novel tetrazolium-based assay. Cancer Res 1989, 49(16):4435-4440. 
18. Watabe M, Kawazoe N, Masuda Y, Nakajo S, Nakaya K: Bcl-2 protein inhibits bufalin-induced apoptosis through inhibition of mitogen-activated protein kinase activation in human leukemia U937 cells. Cancer Res 1997, 57(15):3097-3100.

19. Lee KW, Jung HJ, Park HJ, Kim DG, Lee JY, Lee KT: Beta-D-xylopyranosyl-(1->3)-beta-Dglucuronopyranosyl echinocystic acid isolated from the roots of Codonopsis lanceolata induces caspase-dependent apoptosis in human acute promyelocytic leukemia HL-60 cells. Biol Pharm Bull 2005, 28(5):854-859. https://doi.org/ 10.1248/bpb.28.854.

20. Pavelescu LA: On reactive oxygen species measurement in living systems. J Med Life 2015, 8 Spec Issue:38-42.

21. Eady JJ, Orta T, Dennis MF, Stratford MR, Peacock JH: Glutathione determination by the Tietze enzymatic recycling assay and its relationship to cellular radiation response. $\mathrm{Br} \mathrm{J}$ Cancer 1995, 72(5):1089-1095. https://doi.org/10.1038/bjc.1995.470.

22. Choi JH, Ha J, Park JH, Lee JY, Lee YS, Park HJ, Choi JW, Masuda Y, Nakaya K, Lee KT: Costunolide triggers apoptosis in human leukemia U937 cells by depleting intracellular thiols. Jpn J Cancer Res 2002, 93(12):1327-1333. https://doi.org/ 10.1111/j.1349-7006.2002.tb01241.x.

23. Shin JS, Park SJ, Ryu S, Kang HB, Kim TW, Choi JH, Lee JY, Cho YW, Lee KT: Potent antiinflammatory effect of a novel furan-2,5-dione derivative, BPD, mediated by dual suppression of COX2 activity and LPS-induced inflammatory gene expression via NF-kappaB inactivation. $\mathrm{Br} \mathrm{J}$ Pharmacol 2012, 165(6):1926-1940. https://doi.org/10.1111/j.1476-5381.2011.01670.x.

24. Hong JY, Chung KS, Shin JS, Lee JH, Gil HS, Lee HH, Choi E, Choi JH, Hassan AHE, Lee YS et al: The Anti-Proliferative Activity of the Hybrid TMS-TMF-4f Compound Against Human Cervical Cancer Involves Apoptosis Mediated by STAT3 Inactivation. Cancers (Basel) 2019, 11(12). https://doi.org/10.3390/cancers11121927.

25. O'Neill KL, Huang K, Zhang J, Chen Y, Luo X: Inactivation of prosurvival Bcl-2 proteins activates Bax/Bak through the outer mitochondrial membrane. Genes Dev 2016, 30(8):973-988. https://doi.org/10.1101/gad.276725.115.

26. Wada T, Penninger JM: Mitogen-activated protein kinases in apoptosis regulation. Oncogene 2004, 23(16):2838-2849. https://doi.org/10.1038/sj.onc.1207556.

27. Dhanasekaran DN, Reddy EP: JNK-signaling: A multiplexing hub in programmed cell death. Genes Cancer 2017, 8(9-10):682-694. https://doi.org/10.18632/genesandcancer.155.

28. Elmore S: Apoptosis: a review of programmed cell death. Toxicol Pathol 2007, 35(4):495-516. https://doi.org/10.1080/01926230701320337.

29. Schieber M, Chandel NS: ROS function in redox signaling and oxidative stress. Curr Biol 2014, 24(10):R453-462. https:// doi.org/10.1016/j.cub.2014.03.034.

30. Chen Y, Gan D, Huang Q, Luo X, Lin D, Hu J: Emodin and Its Combination with Cytarabine Induce Apoptosis in Resistant Acute Myeloid Leukemia Cells in Vitro and in Vivo. Cell Physiol Biochem 2018, 48(5):2061-2073. https://doi.org/10.1159/000492544. 
31. Moldogazieva NT, Lutsenko SV, Terentiev AA: Reactive Oxygen and Nitrogen Species-Induced Protein Modifications: Implication in Carcinogenesis and Anticancer Therapy. Cancer Res 2018, 78(21):60406047. https://doi.org/10.1158/0008-5472.CAN-18-0980.

32. Ziech D, Franco R, Georgakilas AG, Georgakila S, Malamou-Mitsi V, Schoneveld O, Pappa A, Panayiotidis Ml: The role of reactive oxygen species and oxidative stress in environmental carcinogenesis and biomarker development. Chem Biol Interact 2010, 188(2):334-339. https://doi.org/10.1016/j.cbi.2010.07.010.

33. Moloney JN, Cotter TG: ROS signalling in the biology of cancer. Semin Cell Dev Biol 2018, 80:50-64. https://doi.org/10.1016/j.semcdb.2017.05.023.

34. Kim MJ, Kim DH, Lee KW, Yoon DY, Surh YJ: Jaceosidin induces apoptosis in ras-transformed human breast epithelial cells through generation of reactive oxygen species. Ann N Y Acad Sci 2007, 1095:483-495. https://doi.org/10.1196/annals.1397.052.

35. Lee CS, Kim YJ, Lee SA, Myung SC, Kim W: Combined effect of Hsp90 inhibitor geldanamycin and parthenolide via reactive oxygen species-mediated apoptotic process on epithelial ovarian cancer cells. Basic Clin Pharmacol Toxicol 2012, 111(3):173-181. https://doi.org/10.1111/j.17427843.2012.00883.x.

36. Choi JH, Lee KT: Costunolide-induced apoptosis in human leukemia cells: involvement of c-jun Nterminal kinase activation. Biol Pharm Bull 2009, 32(10):1803-1808.

https://doi.org/10.1248/bpb.32.1803.

37. Yang YI, Kim JH, Lee KT, Choi JH: Costunolide induces apoptosis in platinum-resistant human ovarian cancer cells by generating reactive oxygen species. Gynecol Oncol 2011, 123(3):588-596. https://doi.org/10.1016/j.ygyno.2011.08.031.

38. Ka H, Park HJ, Jung HJ, Choi JW, Cho KS, Ha J, Lee KT: Cinnamaldehyde induces apoptosis by ROSmediated mitochondrial permeability transition in human promyelocytic leukemia HL-60 cells. Cancer Lett 2003, 196(2):143-152. https://doi.org/ 10.1016/s0304-3835(03)00238-6.

39. Kim JE, Son JE, Jeong H, Joon Kim D, Seo SK, Lee E, Lim TG, Kim JR, Chen H, Bode AM et al: A Novel Cinnamon-Related Natural Product with Pim-1 Inhibitory Activity Inhibits Leukemia and Skin Cancer. Cancer Res 2015, 75(13):2716-2728. https://doi.org/10.1158/0008-5472.CAN-14-3655.

40. Lee SH, Lee SY, Son DJ, Lee H, Yoo HS, Song S, Oh KW, Han DC, Kwon BM, Hong JT: Inhibitory effect of 2'-hydroxycinnamaldehyde on nitric oxide production through inhibition of NF-kappa B activation in RAW 264.7 cells. Biochem Pharmacol 2005, 69(5):791-799. https://doi.org/10.1016/j.bcp.2004.11.013.

41. Xie L, Xiang GH, Tang T, Tang Y, Zhao LY, Liu D, Zhang YR, Tang JT, Zhou S, Wu DH: Capsaicin and dihydrocapsaicin induce apoptosis in human glioma cells via ROS and Ca2+mediated mitochondrial pathway. Mol Med Rep 2016, 14(5):4198-4208. https://doi.org/10.3892/mmr.2016.5784.

42. Lin T, Chen Y, Ding Z, Luo G, Liu J, Shen J: Novel insights into the synergistic interaction of a thioredoxin reductase inhibitor and TRAIL: the activation of the ASK1-ERK-Sp1 pathway. PLoS One 2013, 8(5):e63966. https://doi.org/10.1371/journal.pone.0063966. 
43. Nagai $H$, Noguchi T, Takeda K, Ichijo H: Pathophysiological roles of ASK1-MAP kinase signaling pathways. J Biochem Mol Biol 2007, 40(1):1-6. https://doi.org/ 10.5483/bmbrep.2007.40.1.001.

44. Kasibhatla S, Brunner T, Genestier L, Echeverri F, Mahboubi A, Green DR: DNA damaging agents induce expression of Fas ligand and subsequent apoptosis in T lymphocytes via the activation of NF-kappa B and AP-1. Mol Cell 1998, 1(4):543-551. https://doi.org/10.1016/s1097-2765(00)80054-4.

45. Ameyar M, Wisniewska M, Weitzman JB: A role for AP-1 in apoptosis: the case for and against. Biochimie 2003, 85(8):747-752. https://doi.org/10.1016/j.biochi.2003.09.006.

46. Whitfield J, Neame SJ, Paquet L, Bernard O, Ham J: Dominant-negative c-Jun promotes neuronal survival by reducing BIM expression and inhibiting mitochondrial cytochrome $\mathrm{c}$ release. Neuron 2001, 29(3):629-643. https://doi.org/10.1016/s0896-6273(01)00239-2.

47. Liou GY, Storz P: Reactive oxygen species in cancer. Free Radic Res 2010, 44(5):479-496. https://doi.org/10.3109/10715761003667554.

48. Lee CH, Yao CF, Huang SM, Ko S, Tan YH, Lee-Chen GJ, Wang YC: Novel 2-step synthetic indole compound 1,1,3-tri(3-indolyl)cyclohexane inhibits cancer cell growth in lung cancer cells and xenograft models. Cancer 2008, 113(4):815-825. https://doi.org/10.1002/cncr.23619.

\section{Tables}

Table 1. Effect of 2'-HCA on cancer cell growth in vitro

\begin{tabular}{|lllllllll|}
\hline Cell line & \multicolumn{1}{c}{ Origin } & \multicolumn{5}{c|}{$\mathrm{IC}_{50}(\mu \mathrm{M})$ a) } \\
\cline { 3 - 8 } & & \multicolumn{5}{c}{ 2'-HCA $^{\prime}$} & \multicolumn{3}{c|}{ Cisplatin } \\
\hline HL-60 & Human promyelocytic leukemia & 4.17 & \pm & 0.62 & 17.7 & \pm & 2.54 \\
\hline Molt-4 & Human T lymphoblastic leukemia & 9.14 & \pm & 0.88 & 9.34 & \pm & 1.12 \\
\hline U937 & Human histiocytic lymphoma & 23.25 & \pm & 1.98 & 22.0 & \pm & 2.18 \\
\hline K562 & Human erythroleukemia & 23.15 & \pm & 2.34 & & $>100$ & \\
\hline HepG2 & Human hepatoblastoma & 17.08 & \pm & 1.76 & 54.6 & \pm & 4.88 \\
\hline SNU-C5 & Human colorectal adenocarcinoma & 22.77 & \pm & 2.92 & 27.4 & \pm & 2.76 \\
\hline A549 & Human lung adenocarcinoma & 33.14 & \pm & 3.76 & 47.62 & \pm & 3.87 \\
\hline KB & Human mouth epidermal carcinoma & 53.04 & \pm & 4.91 & 56.43 & \pm & 4.99 \\
\hline
\end{tabular}

a) ${ } C_{50}$ is defined as the concentration that results in a $50 \%$ decrease in the number of cells compared with that of the control cultures in the absence of 2'-HCA. The values represent the mean of three independent experiments.

\section{Figures}




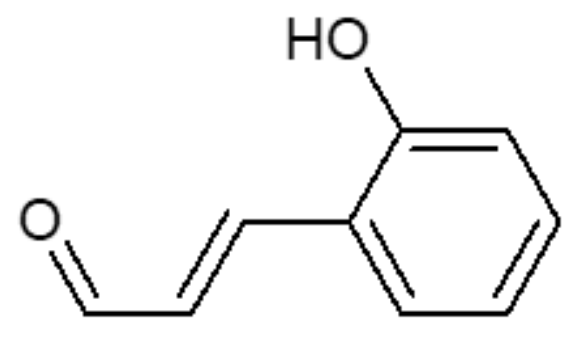

Figure 1

Chemical structure of 2'-HCA.

Administration

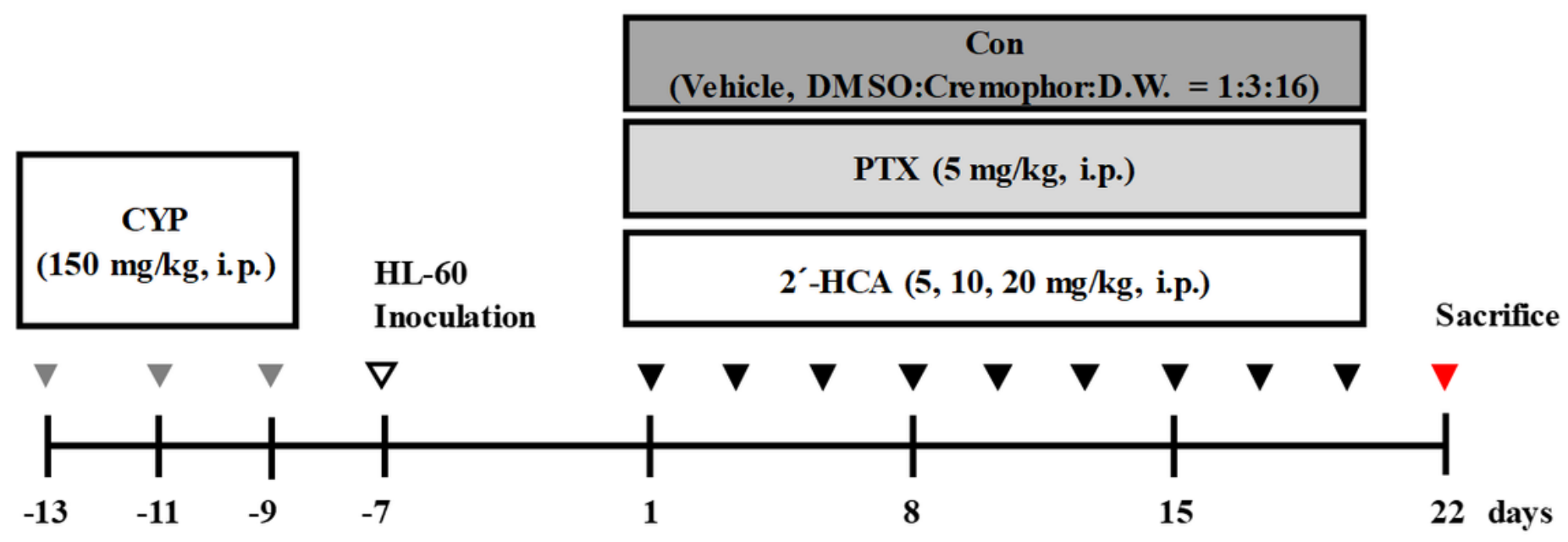

Figure 2

Scheme of the experimental procedure using HL-60 cell-inoculated xenograft animals for assessing the anti-tumor efficacy of 2'-HCA. 
A

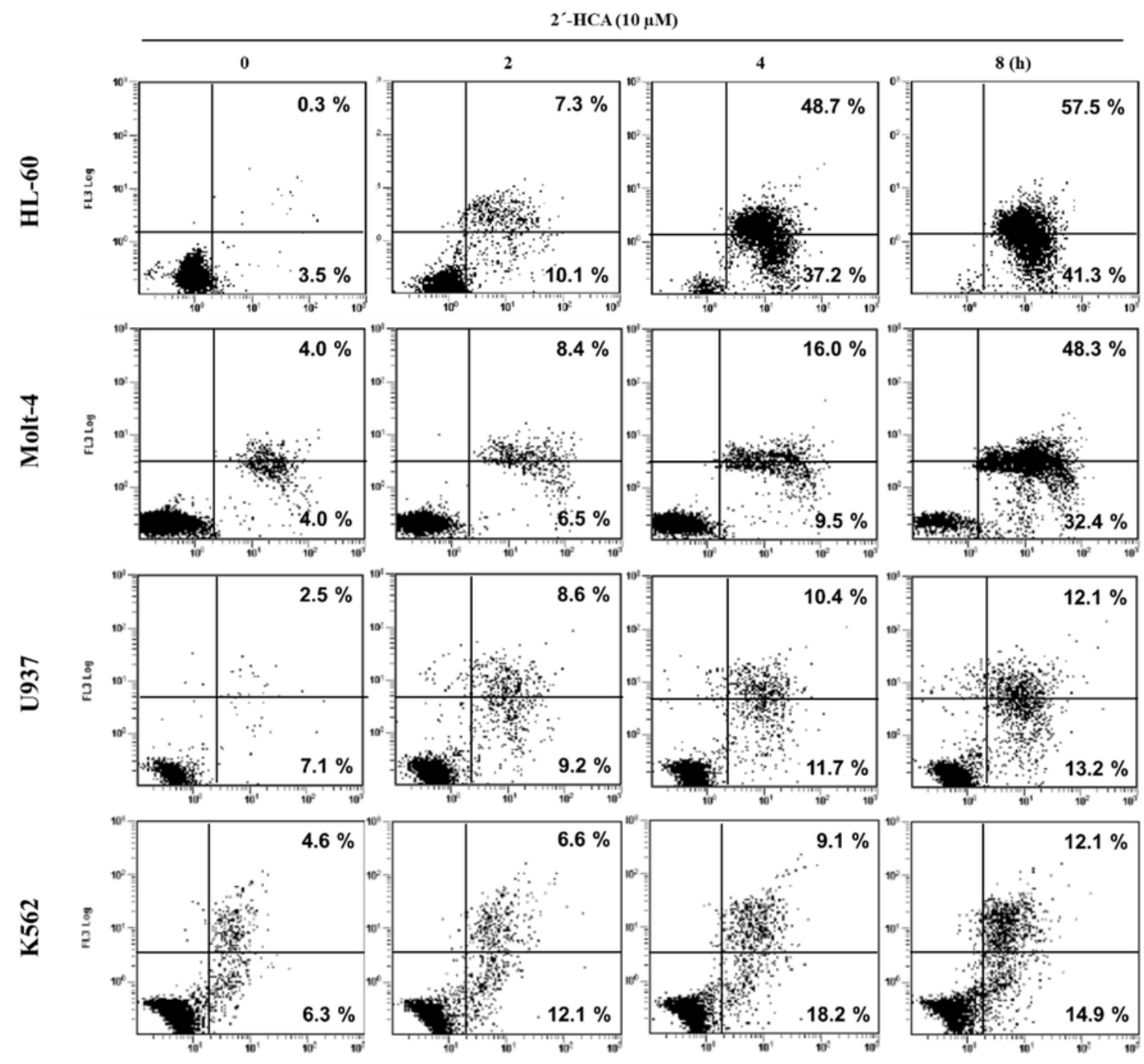

B

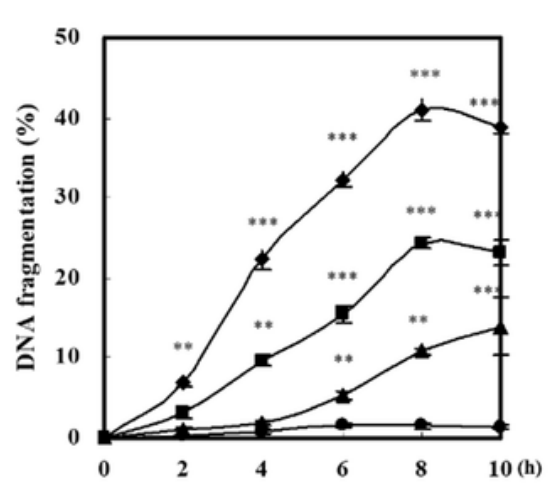

C

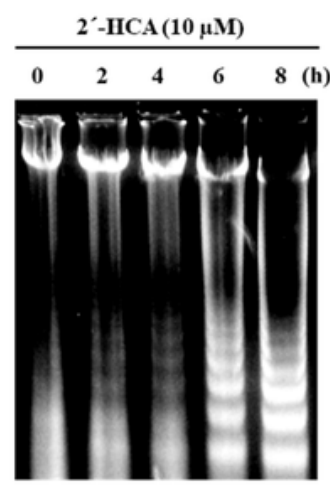

Figure 3

Effects of 2'-HCA on the induction of apoptosis and DNA fragmentation in HL-60 cells. (A) HL-60 cells were co-stained with Annexin V-FITC/PI after treatment with $10 \mu \mathrm{M}$ 2'-HCA to detect the externalization of phosphatidylserine (PS) followed by flow cytometric analysis. HL-60 cells were treated with $10 \mu \mathrm{M} 2$ '-HCA for the indicated period, and the extent (\%) of DNA fragmentation was determined by (B) DAPI assay and (C) agarose gel electrophoresis as described in the Materials and Methods section. Data are presented as 
the mean \pm SD of three independent experiments $\left(O, 0 \mu \mathrm{M} ; \boldsymbol{\Delta}, 2.5 \mu \mathrm{M} ; \boldsymbol{\square}, 5 \mu \mathrm{M} ; \nabla, 10 \mu \mathrm{M} 2^{\prime}-\mathrm{HCA}\right)$. ${ }^{\star \star} \mathrm{P}<$ $0.01, * \star \star P<0.001$ vs. control group.

A

\begin{tabular}{cccccc}
\multicolumn{5}{c}{$2^{\prime}-\mathrm{HCA}(10 \mu \mathrm{M})$} \\
\hline 0 & 2 & 4 & 6 & 8 (h)
\end{tabular}

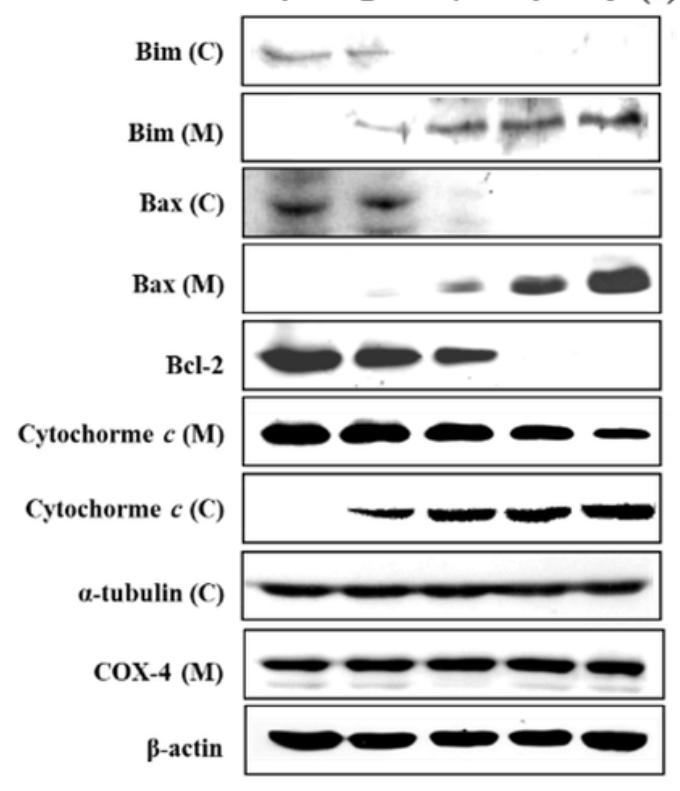

C

\begin{tabular}{cccccc}
\multicolumn{5}{c}{$2^{\prime}-\mathrm{HCA}(10 \mu \mathrm{M})$} \\
\hline 0 & 2 & 4 & 6 & 8 & (h)
\end{tabular}

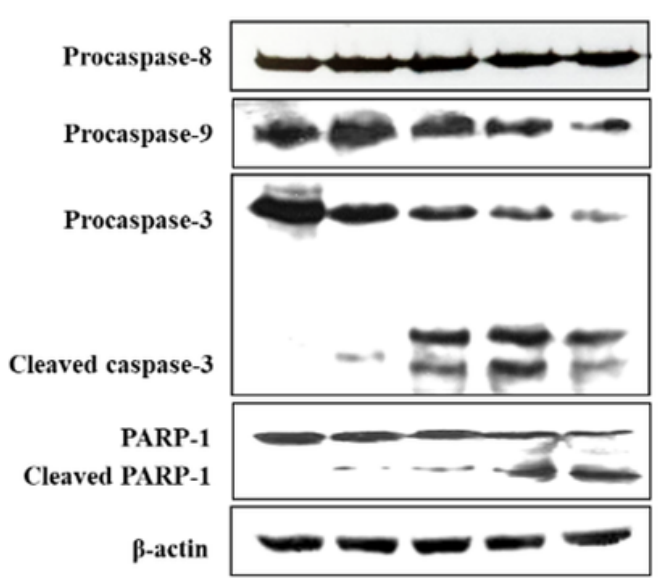

B

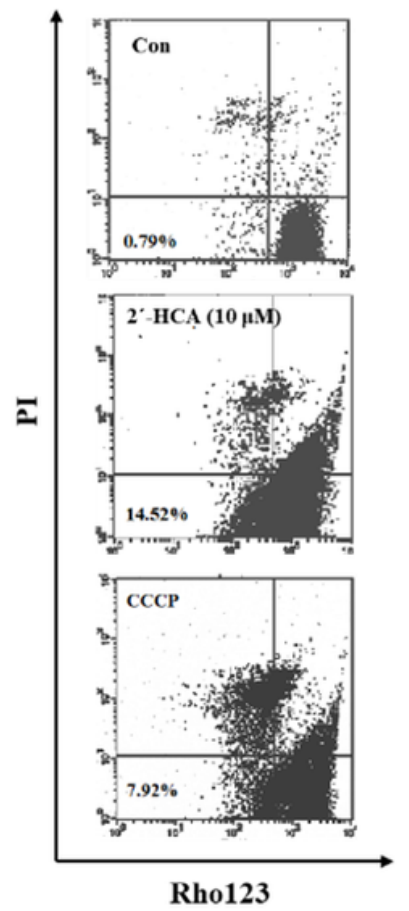

D

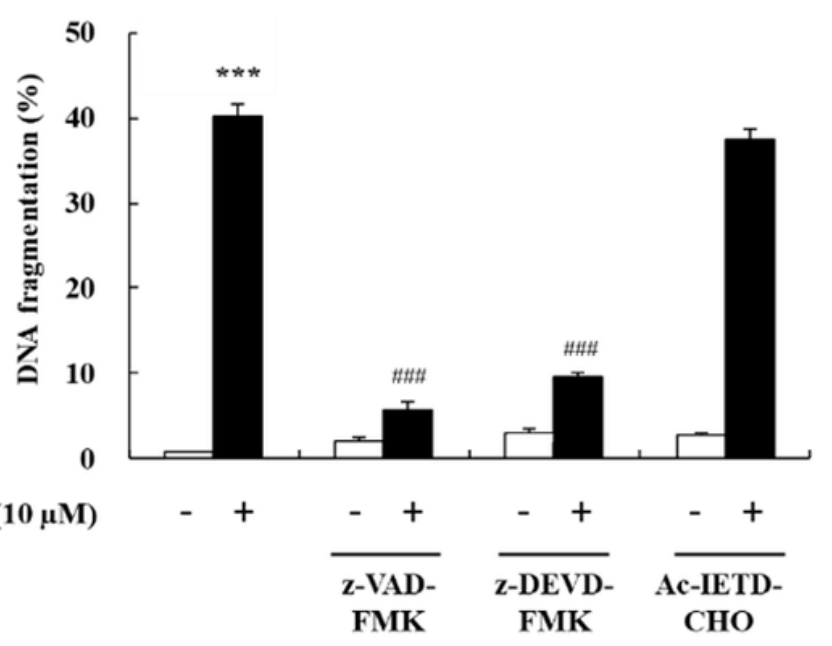

Figure 4

Effects of 2'-HCA on mitochondrial dysfunction and caspase activation in HL-60 cells. (A) Representative western blots showing changes in the protein levels of Bim, Bax, Bcl-2, and cytochrome $\mathrm{c}$ after treatment with $10 \mu \mathrm{M}$ 2'-HCA for the indicated times in HL-60 cells (C: cytosol, M: mitochondria). a-tubulin, COX 4, and $\beta$-actin were used as internal controls. (B) HL-60 cells were treated with $10 \mu \mathrm{M}$ 2'-HCA for $1 \mathrm{~h}$, and $\square \Psi \mathrm{m}$ was determined using rhodamine 123 and PI by flow cytometry. (C) Representative western blots showing changes in the protein levels of procaspase-9, procaspase-3, cleaved caspase-3, PARP-1, and 
cleaved PARP-1 after incubation with $10 \mu \mathrm{M}$ 2'-HCA for the indicated times in HL-60 cells. $\beta$-actin was used as an internal control. (D) HL-60 cells were pretreated with or without caspase inhibitors $(50 \mu \mathrm{M} \mathrm{z-}$ VAD-FMK, $50 \mu \mathrm{M} z$-DEVD-FMK, or $50 \mu \mathrm{M}$ Ac-IETD-CHO) for $1 \mathrm{~h}$ and treated with $10 \mu \mathrm{M} 2$ '-HCA for $8 \mathrm{~h}$. The extent (\%) of DNA fragmentation was determined by DAPI assay as described in the Materials and Methods section. Data are presented as the mean \pm SD of three independent experiments. ${ }^{* \star *} \mathrm{P}<0.001$ vs. control group, \#P < 0.05, \#\#\# < 0.001 vs. 2'-HCA-treated group.

A 2 -HCA (10 $\mu \mathrm{M})$

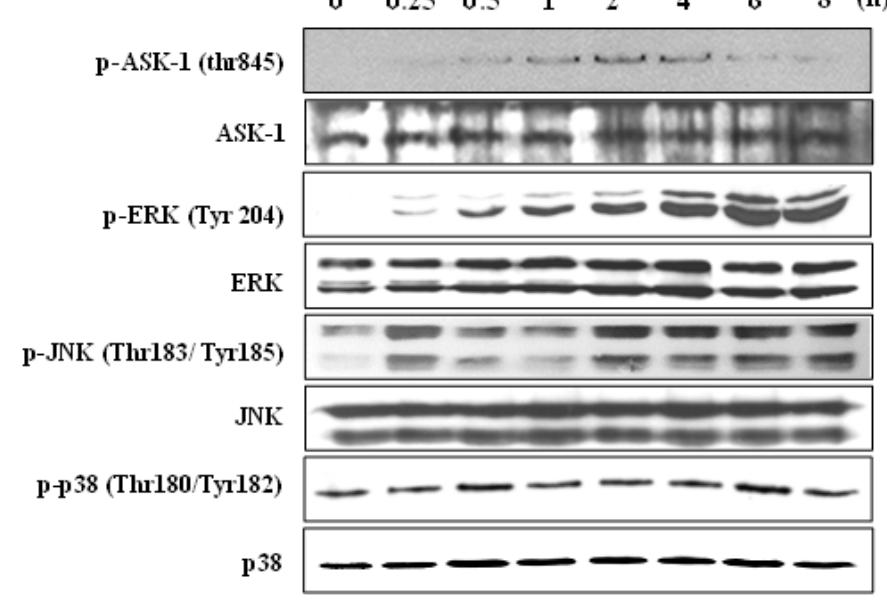

$\mathbf{E}$

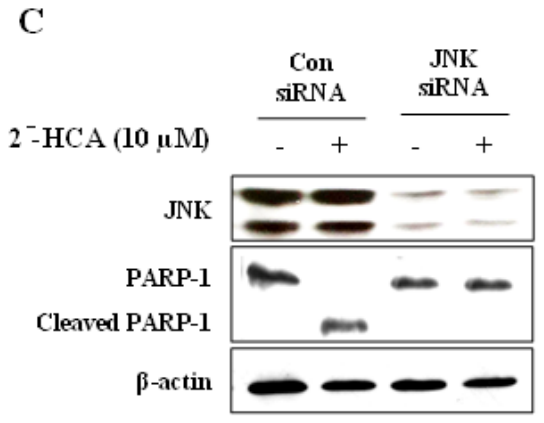

B

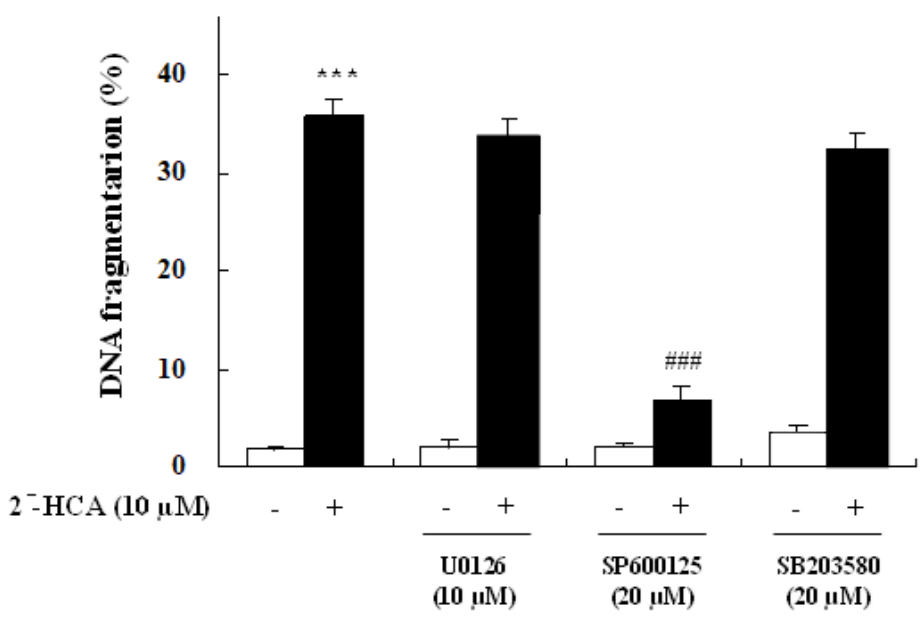

D

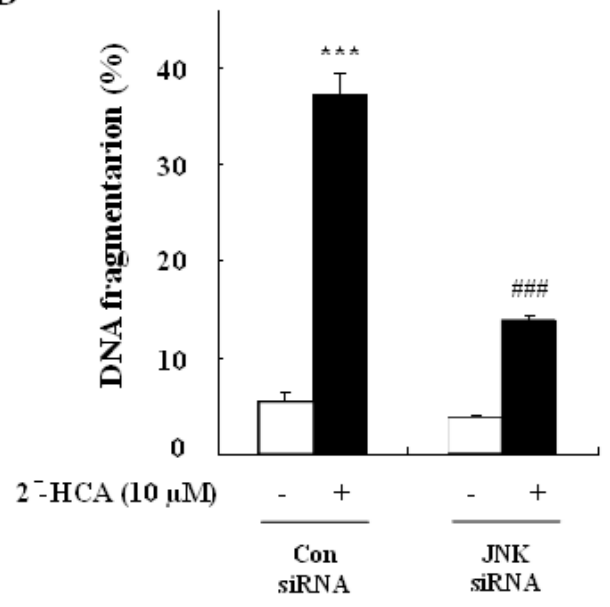

F

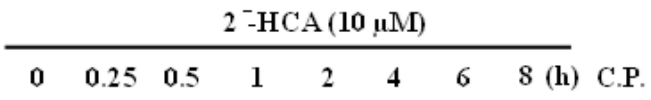

AP-1

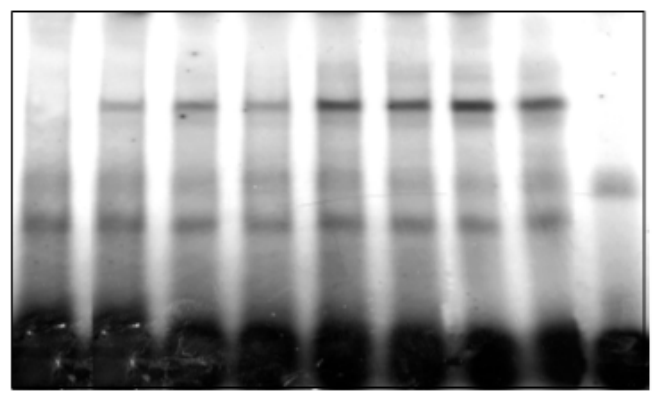

Figure 5 
Effect of 2'-HCA on MAPK activation in HL-60 cells. (A) Representative western blots showing changes in the protein levels of p-ASK-1, p-ERK1/2, ERK1/2, p-JNK, JNK, p-p38 MAPK, and p38 MAPK after treatment with $10 \mu \mathrm{M} 2$ '-HCA for the indicated times in HL-60 cells. $\beta$-actin was used as an internal control. (B) After pretreatment with MAPK inhibitors (U0126, ERK1/2 inhibitor; SP600125, JNK inhibitor; SB203580, p38 MAPK inhibitor) for $1 \mathrm{~h}, \mathrm{HL}-60$ cells were treated with $10 \mu \mathrm{M}$ 2'-HCA for $8 \mathrm{~h}$, and the extent (\%) of DNA fragmentation was determined by DAPI assay. ( $C$ and $D$ ) JNK siRNA-transfected HL-60 cells were treated with $10 \mu \mathrm{M} 2$ '-HCA for $8 \mathrm{~h}$. The levels of protein expression and DNA fragmentation were determined by western blotting and DAPI assay, respectively. (E) HL-60 cells were treated with $10 \mu \mathrm{M}$ 2'-HCA for the indicated times, and JNK activity was determined by JNK kinase assay. (F) Nuclear extracts were prepared from 2'-HCA-treated HL-60 cells and analyzed for AP-1 DNA-binding activity by EMSA. A competition experiment using a 5 -fold excess of cold oligonucleotides (C.P.) indicated that DNA binding was specific. Data are presented as the mean $\pm S D$ of three independent experiments. ${ }^{\star \star *} P<0.01 \mathrm{vs}$. control group, \#P<0.05, \#\#\# < 0.001 vs. 2'-HCA-treated group. 
A
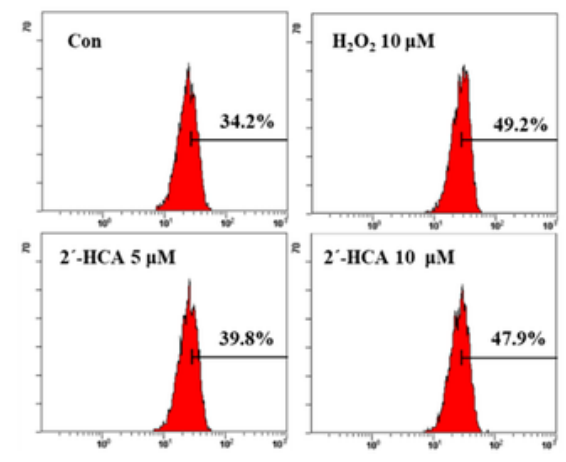

C

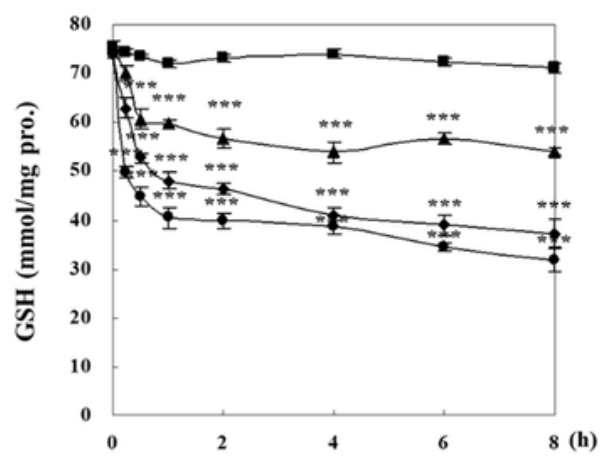

B

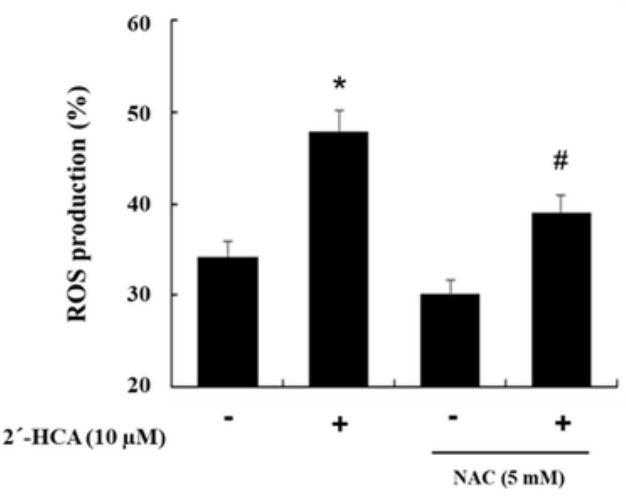

D

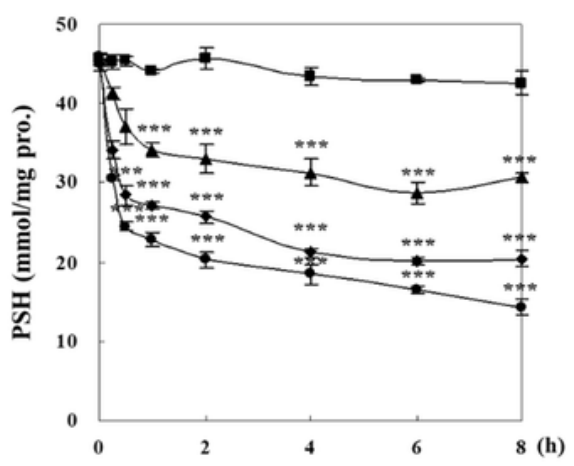

E
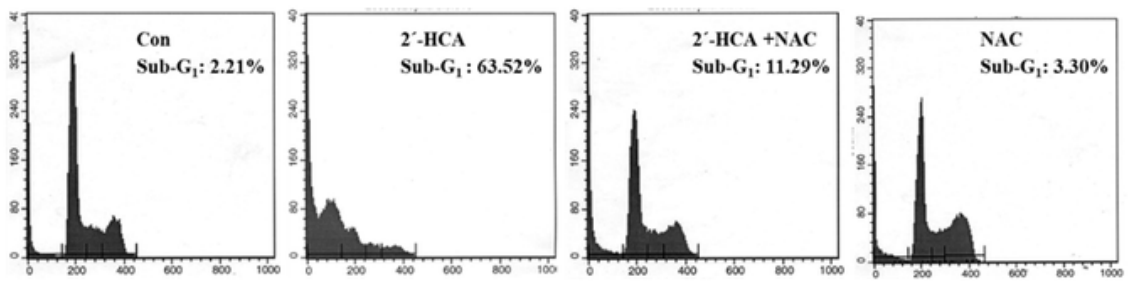

$\mathbf{F}$

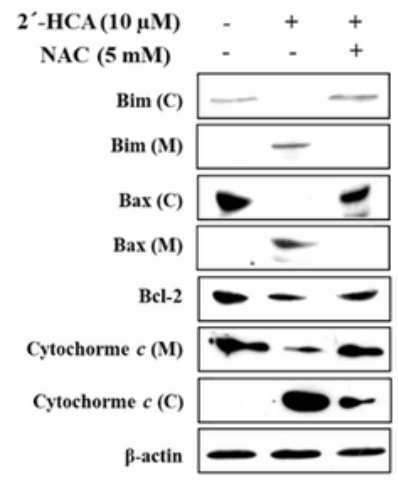

G

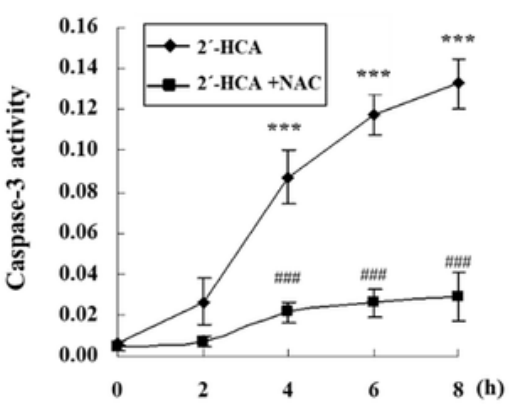

Figure 6

Effects of 2'-HCA on intracellular ROS production in HL-60 cells. (A) HL-60 cells were treated with 2'-HCA or $\mathrm{H} 2 \mathrm{O} 2$ for 5 min. ROS levels were determined with a DCFH-DA staining and the fluorescent intensity was measured by flow cytometry. (B) After pretreatment with $5 \mathrm{mM} \mathrm{NAC}$ for $1 \mathrm{~h}, \mathrm{HL}-60$ cells were treated with $10 \mu \mathrm{M}$ 2'-HCA for 5 min. The levels of intracellular (C) GSH and (D) PSH were determined in 2'-HCAtreated HL-60 cells $(\Theta, 0 \mu \mathrm{M} ; \boldsymbol{\Lambda}, 2.5 \mu \mathrm{M} ; \boldsymbol{\square}, 5 \mu \mathrm{M} ; \bigotimes, 10 \mu \mathrm{M}$ 2'-HCA). After pretreatment with $5 \mathrm{mM}$ NAC for 
$1 \mathrm{~h}, \mathrm{HL}-60$ cells were treated with $10 \mu \mathrm{M}$ 2'-HCA for $8 \mathrm{~h}$, and (D) sub-G1 and (E) mitochondria-related protein expression was detected by PI staining and western blotting, respectively. $\alpha$-tubulin, COX-4, and $\beta$ actin were used as internal controls. (F) The effect of NAC on caspase-3 activity was examined in 2'-HCAtreated HL-60 cells. Data are presented as the mean \pm SD of three independent experiments. ${ }^{*} \mathrm{P}<0.05$,

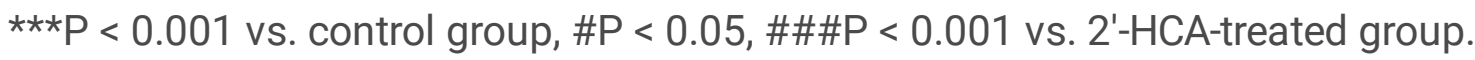
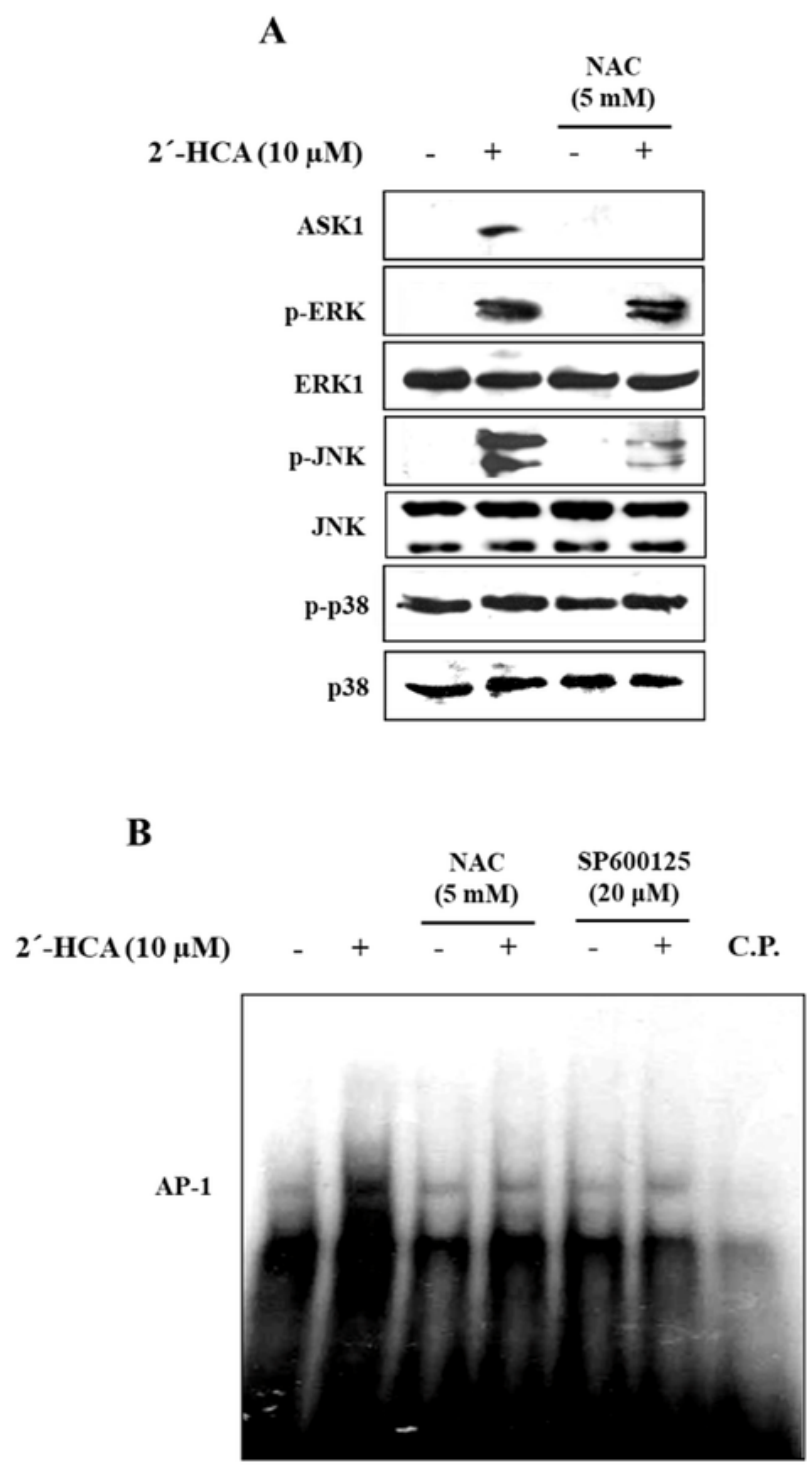

C

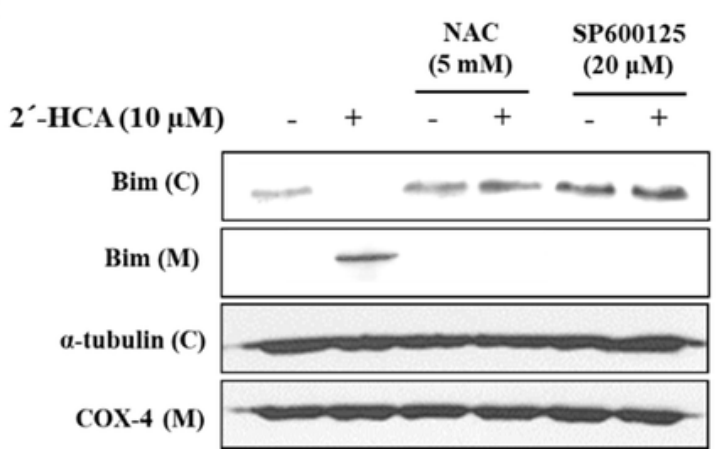

Figure 7 
Effect of 2'-HCA-activated ROS on MAPK activation in HL-60 cells. (A) Representative western blots showing changes in the protein levels of ASK-1, p-ERK1/2, p-JNK, p-p38 MAPK, ERK1/2, JNK, and p38 MAPK after pretreatment with $5 \mathrm{mM} \mathrm{NAC}$ for $1 \mathrm{~h}$ followed by treatment with $10 \mu \mathrm{M} 2$ '-HCA for $8 \mathrm{~h}$. $\beta$-actin was used as an internal control. (B, C) After pretreatment with $5 \mathrm{mM} \mathrm{NAC}$ or $20 \mu \mathrm{M}$ SP600125 for $1 \mathrm{~h}, \mathrm{HL}-$ 60 cells were treated with $10 \mu \mathrm{M}$ 2'-HCA for $8 \mathrm{~h}$, and AP-1 DNA-binding activity and Bim translocation were analyzed by EMSA and western blotting, respectively. A competition experiment using a 5-fold excess of cold oligonucleotides (C.P.) indicated that DNA binding was specific. a-tubulin and COX 4 were used as internal controls.

A

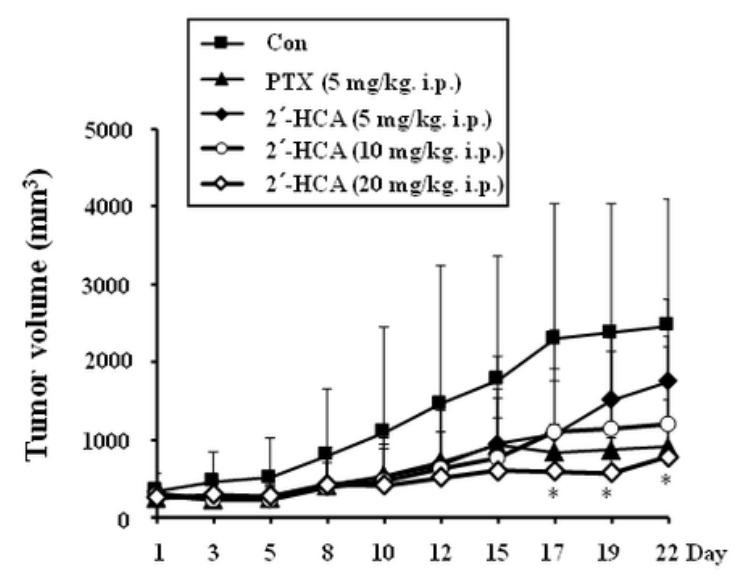

$\mathrm{C}$

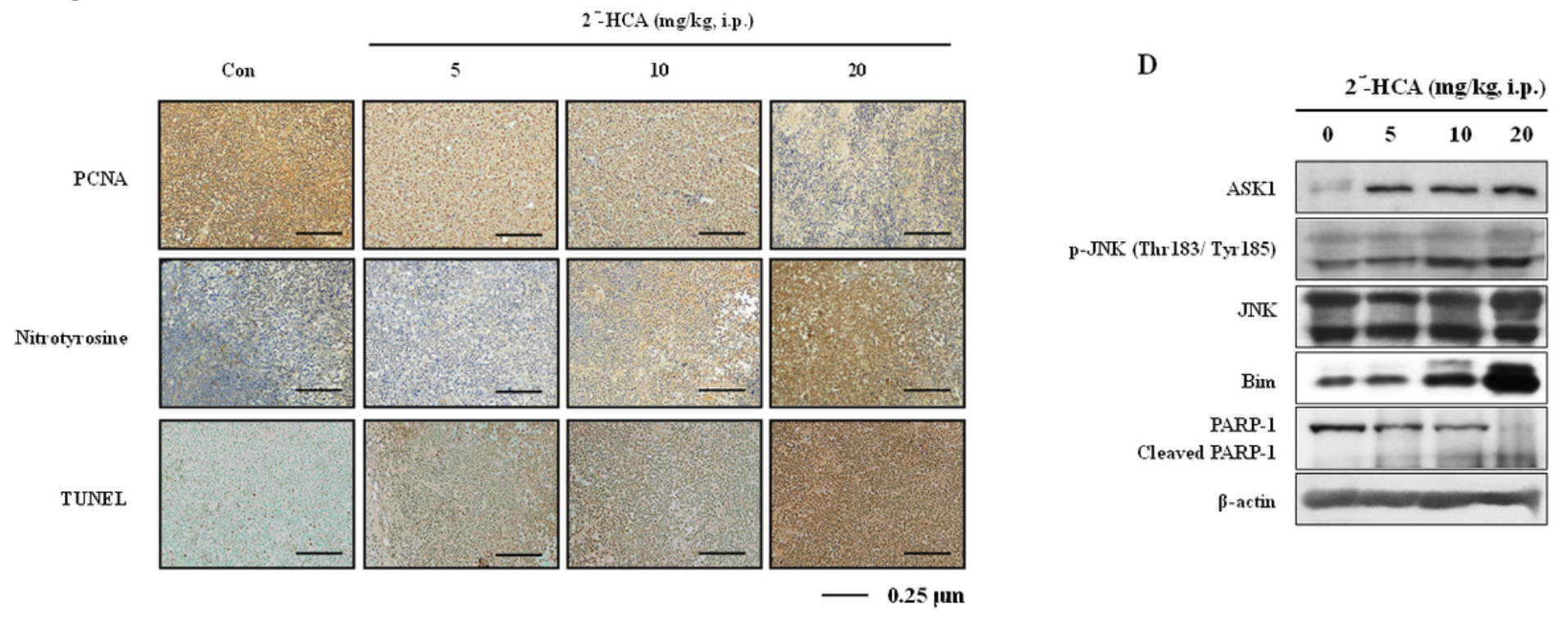

\section{Figure 8}

Effect of 2'-HCA on tumor growth in a HL-60 xenograft mouse model. (A) The tumor volume (mm3) was measured throughout the experimental period, and (B) Representative tumors were selected after the mice were sacrificed. Data are presented as the mean $\pm S D(n=6)$. ${ }^{*}<0.05$ vs. control group. (C) The 
expression levels of PCNA and nitrotyrosine were analyzed by $\mathrm{IHC}$ and apoptosis induction was examined by TUNEL assay in tumor tissues. (D) Intratumoral expression of ASK1, p-JNK, Bim, and PARP1 were evaluated by western blotting. $\beta$-actin was used as an internal control.

\section{Supplementary Files}

This is a list of supplementary files associated with this preprint. Click to download.

- SupplementalFigure.docx 